WSRC-TR-2001-00158, Revision 0

\title{
MELT RATE IMPROVEMENT FOR DWPF MB3: Sugar Addition Test (U)
}

J. E. Josephs

M. E. Stone

Westinghouse Savannah River Company

Savannah River Site

Aiken, SC 29808

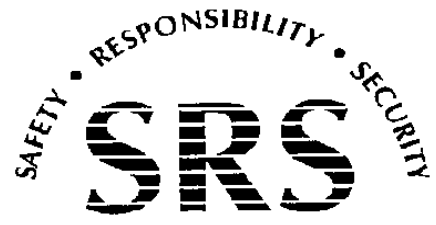

PREPARED FOR THE U.S. DEPARTMENT OF ENERGY UNDER CONTRACT NO. DE-AC09-96SR18500 
This document was prepared in conjunction with work accomplished under Contract No.

DE-AC09-96SR18500 with the U.S. Department of Energy.

\section{DISCLAIMER}

This report was prepared as an account of work sponsored by an agency of the United States Government. Neither the United States Government nor any agency thereof, nor any of their employees, makes any warranty, express or implied, or assumes any legal liability or responsibility for the accuracy, completeness, or usefulness of any information, apparatus, product or process disclosed, or represents that its use would not infringe privately owned rights. Reference herein to any specific commercial product, process or service by trade name, trademark, manufacturer, or otherwise does not necessarily constitute or imply its endorsement, recommendation, or favoring by the United States Government or any agency

thereof. The views and opinions of authors expressed herein do not necessarily state or reflect those of the United States Government or any agency thereof.

This report has been reproduced directly from the best available copy.

Available for sale to the public, in paper, from: U.S. Department of Commerce, National Technical Information Service, 5285 Port Royal Road, Springfield, VA 22161, phone: (800)

553-6847, fax: (703) 605-6900, email: orders@ntis.fedworld.gov online ordering: http://www.ntis.gov/ordering.htm

Available electronically at http://www.doe.gov/bridge

Available for a processing fee to U.S. Department of Energy and its contractors, in paper, from: U.S. Department of Energy, Office of Scientific and Technical Information, P.O. Box 62, Oak Ridge, TN 37831-0062, phone: (865 ) 576-8401, fax: (865) 576-5728, email: reports@ adonis.osti.gov 
WSRC-TR-2001-00158, Revision 0

Keywords: Redox

Volume expansion

Retention: Permanent

\section{MELT RATE IMPROVEMENT FOR DWPF MB3: Sugar Addition Test (U)}

J. E. Josephs

M. E. Stone

Publication Date: March 21, 2001

Westinghouse Savannah River Company

Savannah River Site

Aiken, SC 29808

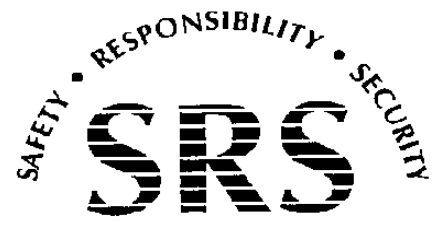

SAVANNAH RIVER SITE

PREPARED FOR THE U.S. DEPARTMENT OF ENERGY UNDER CONTRACT NO. DE-AC09-96SR18500 
APPROVALS

fame i Mach

E. Josephs, Coauthor

ME ft

M. E. Stone, Co-author

$\frac{4-30-01}{\text { Date }}$

and tat

D. P. Lambert, Technical Reviewer

$\frac{4 / 30 / 01}{\text { Date }}$

Shaven I Mara

S. L. Mara, Manager

$\frac{4 / 30 / 01}{\text { Date }}$

Enttalzahute

E. W. Holtzscheiter, Manager

$\frac{5 / 3 / 01}{\text { Date }}$

$\frac{5 / 7 / 01}{\text { Date }}$ 
WSRC-TR-2001-00158

Page $v$ of vi

\section{ACKNOWLEDGEMENTS}

The authors would like to thank the other members of the melt rate team, which includes Denny Bickford, Hector Guerrero, Carol Jantzen, Dan Lambert, Troy Lorier, Sharon Marra, David Peeler, Jim Sproull, and Doug Witt, for their insightful technical direction. We also appreciate the assistance of the many SRTC technicians, their supervisors, and interns that have supported these tasks, especially Frances Williams, Tony Burckhalter, Jon DuVall, Sammie King, Mary Moss, and Vickie Williams. We especially appreciated the direction and support from the DWPF and HLW engineers especially Dick O'Driscoll, Richard Edwards, Hank Elder, Dan Iverson, Michael Norton, and John Occhipinti. The glass shop technicians, Gary Dobos and Curt Sexton, provided capable and timely help in sectioning the crucibles. Special thanks goes to Stacie Owens for providing clerical assistance. Technical management and guidance of this task came from Sharon Marra and Bill Holtzscheiter. 


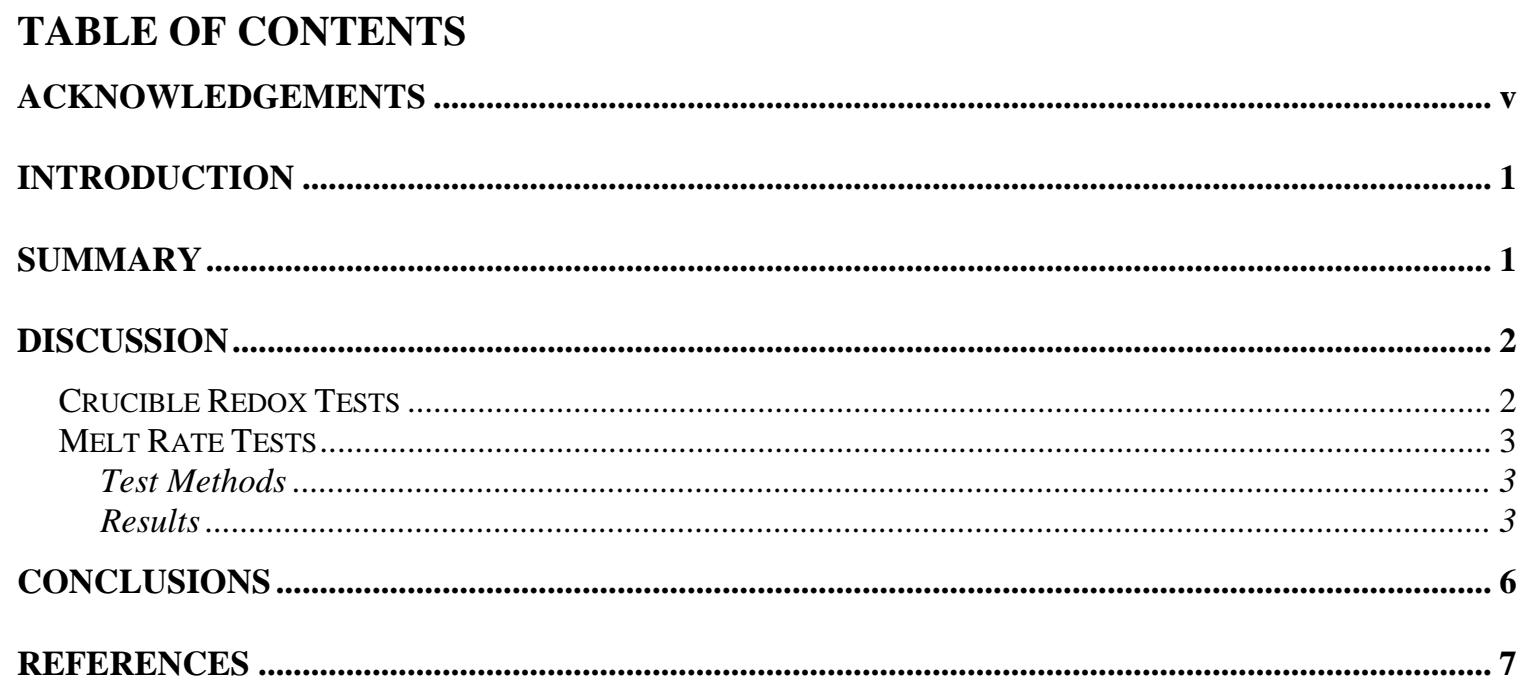

\section{LIST OF FIGURES}

Figure 1. Glass Redox versus Sugar Addition..........................................................2

Figure 2. Pre-sectioned Beaker for 200-MB3-SUGAR-MRF ........................................4

Figure 3. Temperature versus Run Time ...........................................................................5

Figure 4. Sectioned Beaker for 200-MB3-SUGAR-MRF ...........................................5

\section{LIST OF TABLES}

Table 1. Glass Redox Results ............................................................................................2

Table 2. Melt Rate Comparison.....................................................................................................

Table 3. Melt Rate Determination .................................................................................................6 
WSRC-TR-2001-00158

Page 1 of 7

\section{INTRODUCTION}

In order to meet certain production goals, the Defense Waste Processing Facility (DWPF) has focused on implementing a more temporally efficient method of waste vitrification $[1,2]$. Changes in frit composition and alterations in the feed preparation process were investigated to determine if melt rate could be improved. The addition of sugar as an alternative reductant to formic acid was investigated for Macrobatch 3 (MB3).

In the past, experimental data from tests using Macrobatch 2 (MB2) simulant, Frit 200, and varied amounts of sugar (sucrose) showed positive results: a significant decrease in glass expansion and an increase in melt rate. The required amount of sugar needed per sample for nitrate reduction was calculated using the following equation:

$$
4 \mathrm{~N}^{+5}+5 \mathrm{C}^{0} \rightarrow 2 \mathrm{~N}_{2}+5 \mathrm{C}^{+4}
$$

The ratio of carbon to nitrate from the equation is 1.25 moles of carbon per mole of nitrate. This method for determination of the sugar addition resulted in improved melt rates, but led to glass that was more reducing than allowed by DWPF process limits [6].

\section{SUMMARY}

Tests were conducted to determine if the addition of sugar to the melter feed for MB3 would improve melt rate and to determine the relationship between the amount of sugar added and the measured redox state of the glass produced. Redox, a measure of how reducing or oxidizing the glass is, is defined as the ratio of reduced iron $\left(\mathrm{Fe}^{+2}\right)$ to the total iron present in the glass. The redox target in DWPF is $0.20 \mathrm{Fe}^{+2} / \Sigma \mathrm{Fe}$. The importance of the redox state of the glass is that an oxidizing glass will reduce as the temperature increases and release oxygen $\left(2 \mathrm{MnO}_{2} \rightarrow 2 \mathrm{MnO}+\mathrm{O}_{2}\right)$. This oxygen release can lead to foaming in the melt pool and limit melt rate.

The FY01 melt rate tests with MB3 indicated that sugar addition caused a significant increase in the foam generation and a decrease in melt rate, conflicting with results of tests during the MB2 melt rate tests which showed dramatic reductions in the amount of foam generation and significant improvement in melt rate. Changes made to the feed preparation for melt rate testing may have caused the change in behavior; additional tests would be required to verify the cause.

The crucible tests conducted to determine the relationship between the amount of sugar added to the melter feed and the redox state of the glass indicated that the relationship is probably not linear and that small changes in the amount of sugar can significantly increase the redox of the glass. The redox of the glass produced when sufficient sugar is added to reduce the nitrate in the melter feed to nitrogen is above the upper redox limit for DWPF processing. 
WSRC-TR-2001-00158

Page 2 of 7

\section{DISCUSSION}

\section{Crucible Redox Tests}

Crucible tests were conducted with Macrobatch 3 SRAT product and Frit 200 with varying amounts of sugar to determine the impact of sugar on the measured redox of the glass product. SRAT product 15-2 [10], with a nitrate concentration of 10,100 ppm, was utilized for the crucible study. The required amount of sugar per 45 grams of glass was calculated to be 0.38 grams based on a ratio of 1.25 moles of carbon per mole of nitrate as determined during MB2 tests. Thirteen samples were tested with varying amounts of sugar per the redox measurement procedure GTOP-3-046, Revision 4. Each crucible was sealed with nepheline gel and fired for one hour at $1150^{\circ} \mathrm{C}$ [9].

The SRTC Mobile Laboratory determined the redox. The average results are shown in Table 1 and plotted in Figure 1. Based on previous redox studies, a sealed crucible should give a conservative (most reduced) value for the glass redox versus an open crucible [11]. The DWPF melter and the melt rate furnace are not sealed, therefore the redox under true melter conditions would be less. The redox of DWPF glass is not measured, so the amount of conservatism in the sealed crucible test is not known.

Table 1. Glass Redox Results

\begin{tabular}{|c|c|c|c|}
\hline $\begin{array}{c}\text { Amount of Sugar } \\
\text { (grams) }\end{array}$ & $\begin{array}{c}\text { Amount of Sugar } \\
\text { (grams / gram of glass) }\end{array}$ & $\begin{array}{c}\text { Total Number of } \\
\text { Batched Crucibles }\end{array}$ & $\begin{array}{c}\text { Redox Results } \\
\mathrm{Fe}^{+2} / \Sigma \mathrm{Fe}\end{array}$ \\
\hline 0.00 & 0.00 & 3 & 0.17 \\
\hline 0.10 & 0.0022 & 3 & 0.18 \\
\hline 0.20 & 0.0044 & 3 & 0.31 \\
\hline 0.26 & 0.0058 & 2 & 0.32 \\
\hline 0.32 & 0.0071 & 1 & 0.36 \\
\hline 0.38 & 0.0084 & 1 & 0.36 \\
\hline
\end{tabular}

Figure 1. Glass Redox versus Sugar Addition

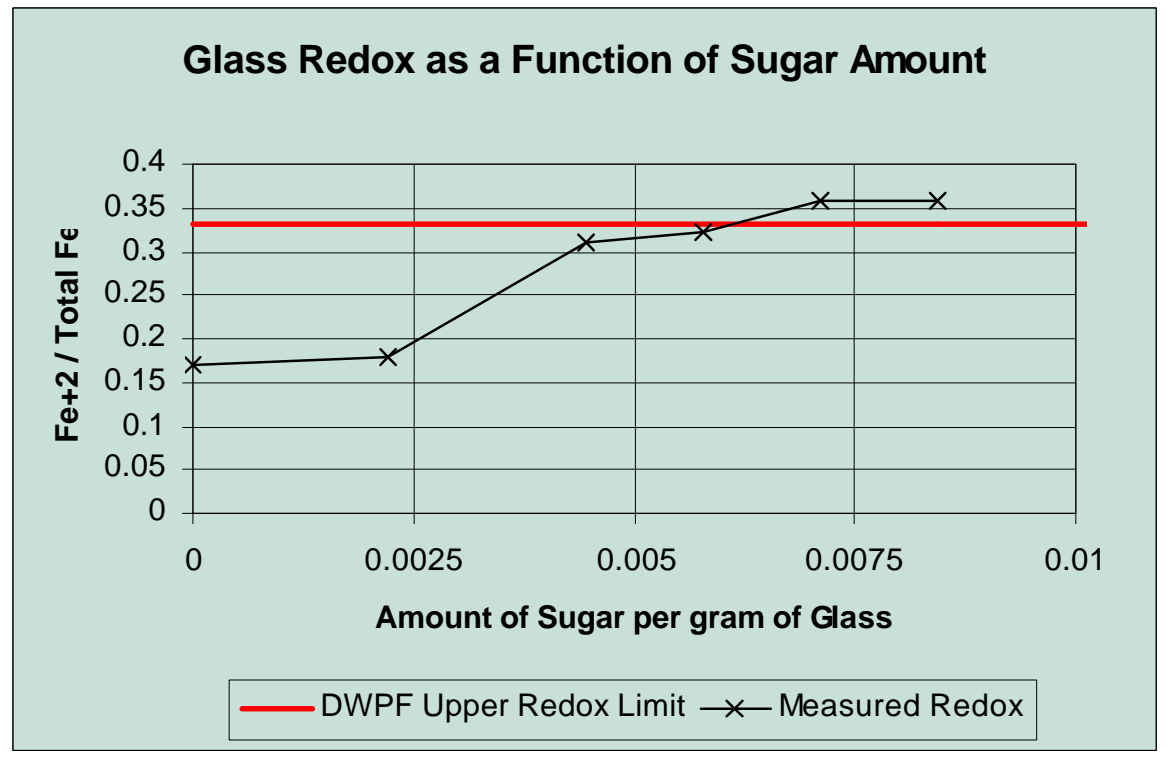


WSRC-TR-2001-00158

Page 3 of 7

The tests indicate that very small changes in the amount of sugar are capable of significantly changing the redox of the glass product and that the required amount of sugar based on the ratio to nitrate is above the redox limit in DWPF. The number of runs is not sufficient to develop a correlation for redox based on the amount of sugar present, but a non-linear function is suggested by the limited data.

\section{Melt Rate Tests}

\section{Test Methods}

The baseline Macrobatch 3 SRAT product (Batch 15-3/4) [10], with a nitrate concentration of $12,800 \mathrm{ppm}$, was combined with 5.83 grams of sugar during the melt rate furnace test to produce 500 grams of glass [8]. The SRAT product, Frit 200, and sugar were combined as a slurry then dried to a batch weight of 551 grams. The melt rate test was conducted in the melt rate furnace in the same manner as the alternative frit tests [5] and was assigned run number 200-MB3-SUGAR-MRF.

\section{Results}

The addition of sugar to the Macrobatch 3 baseline SRAT product did not improve melt rate, as shown in Table 2. In addition, a severe volume expansion was noted during the run with the batch height rising to within 1 inch of the top of the beaker, as shown in Figure 2 and indicated by the rapid rise in temperature of the 2 " thermocouple, as shown in Figure 3. The results are in direct contrast with the results obtained during tests with Macrobatch 2. The differences between the feed preparation process used during this test and the MB2 test may explain the difference in the impact of the sugar addition. Melt rate was determined by the linear and volumetric methods utilized during alternative frit tests, as calculated in Table 3, based on the sectioned beaker shown in Figure 4.

Table 2. Melt Rate Comparison

\begin{tabular}{|l|c|c|c|}
\hline & $\begin{array}{c}\text { Sugar Amount } \\
\text { (gram/gram } \\
\text { glass) }\end{array}$ & $\begin{array}{c}\text { Melt Rate } \\
(\mathrm{in} / \mathrm{hr})\end{array}$ & $\begin{array}{c}\text { Melt Rate } \\
\left(\mathrm{in}^{3} / \mathrm{hr}\right)\end{array}$ \\
\hline Baseline Process & 0 & 0.75 & 11.0 \\
\hline Baseline Process with Sugar & 0.012 & 0.70 & 9.2 \\
\hline
\end{tabular}

During the MB2 melt rate test with sugar, oxidizing SRAT product (mostly nitric acid added during SRAT cycle) was utilized. The SRAT products were dried and sizereduced prior to addition of frit. This method produced a batch with frit as the continuous phase with very large particles of SRAT product. Severe volume expansions were noted during the MB2 melt rate tests with the oxidizing SRAT product when sugar was not added. The sugar was never dissolved in a slurry and did not undergo a drying process prior to the melt rate furnace test since the 42 grams of sugar $(0.084$ grams sugar per gram of glass) were added to dried SRAT product. The sugar eliminated the volume expansion and dramatically increased the observed melt rate [6]. 
Baseline SRAT product was prepared during MB3 by processing the sludge simulant in a SRAT cycle with nitric acid and formic acid addition to target a redox of $0.2 \mathrm{Fe}^{+2} / \Sigma \mathrm{Fe}$. The sugar and frit were added to the SRAT product slurry instead of dried SRAT product. The prepared feed was then dried and size-reduced prior to testing in the melt rate furnace. Less than 6 grams of sugar was required to reduce the nitrate in the baseline feed. The dissolution of sugar in the melter feed slurry may have affected the rheology of the feed and/or the dissolution and drying processes may have affected the sugar, causing the volume expansion noted during the test.

Volume expansions were not observed during Macrobatch 3 tests, except for the run with sugar. A run was conducted with the MB2 feed (oxidizing and reducing slurry blended to target a $0.2 \mathrm{Fe}^{+2} / \Sigma \mathrm{Fe}$ redox) prepared in the same manner as the MB3 tests with no observed volume expansion [5]. The volume expansion is mitigated by the feed preparation method used during MB3, which is closer to the process that will occur in DWPF than the method used during MB2 tests.

\section{Figure 2. Pre-sectioned Beaker for 200-MB3-SUGAR-MRF}

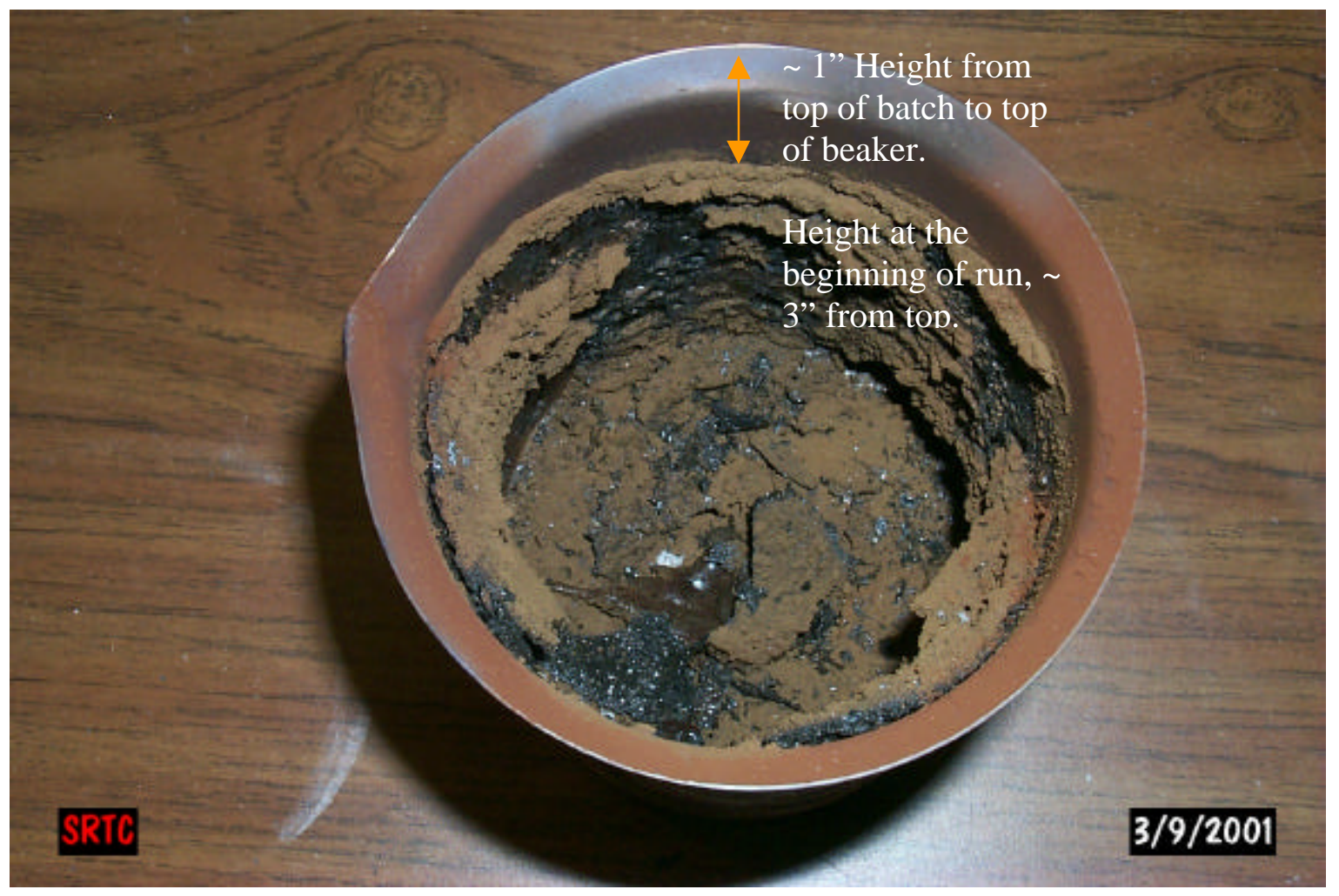


Figure 3. Temperature versus Run Time

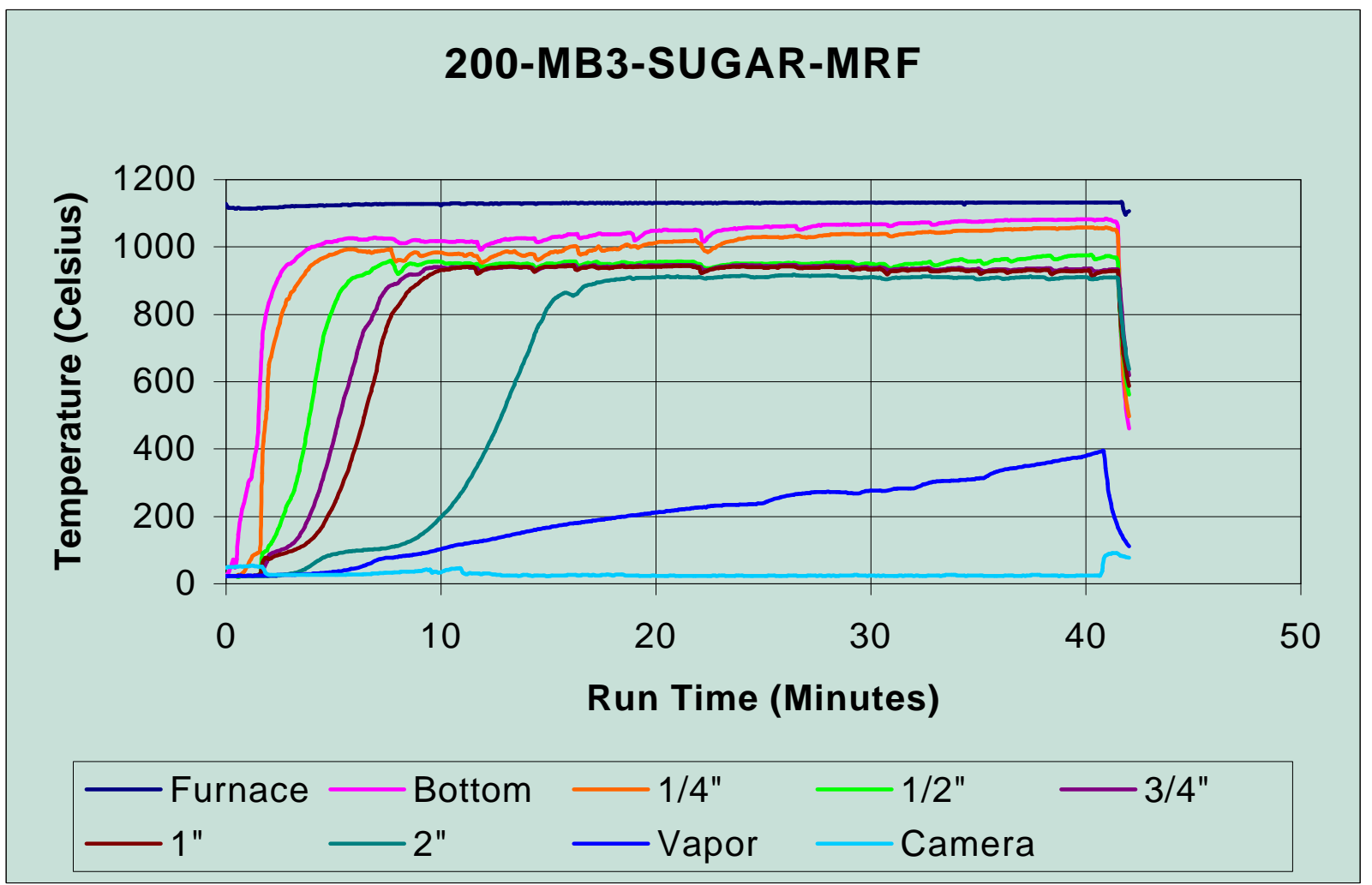

Figure 4. Sectioned Beaker for 200-MB3-SUGAR-MRF

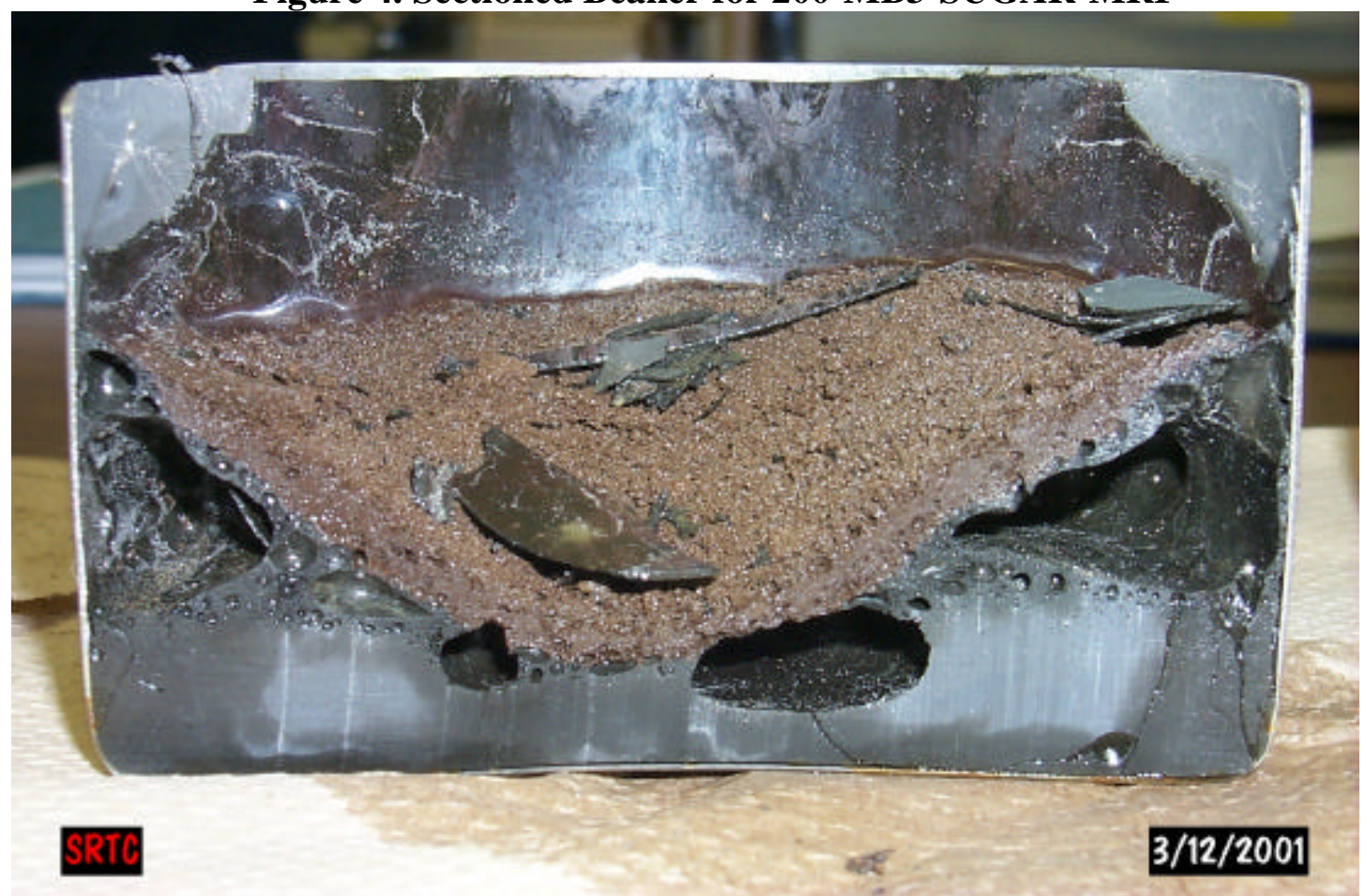


WSRC-TR-2001-00158

Page 6 of 7

Table 3. Melt Rate Determination

\begin{tabular}{|c|c|c|c|c|c|c|c|}
\hline \multicolumn{4}{|c|}{ Linear Melt Rate Determination: in/hr } & \multicolumn{4}{|c|}{$\begin{array}{l}\text { Volumetric Melt Rate Determination: Cubic } \\
\text { inches per hour }\end{array}$} \\
\hline $\begin{array}{c}\text { Distance } \\
\text { from } \\
\text { Center }\end{array}$ & $200-8$ & $200-7$ & Sugar & $\begin{array}{c}\text { Distance } \\
\text { from } \\
\text { Center }\end{array}$ & $200-8$ & $200-7$ & Sugar \\
\hline 2 & 0.55 & 0.7 & 0.6 & 2 & 0.81 & 1.03 & 0.88 \\
\hline 1.75 & 0.55 & 0.7 & 0.6 & 1.75 & 0.70 & 0.89 & 0.77 \\
\hline 1.5 & 0.55 & 0.75 & 0.65 & 1.5 & 0.59 & 0.81 & 0.70 \\
\hline 1.25 & 0.55 & 0.7 & 0.6 & 1.25 & 0.49 & 0.62 & 0.53 \\
\hline 1 & 0.55 & 0.7 & 0.5 & 1 & 0.38 & 0.48 & 0.34 \\
\hline 0.75 & 0.55 & 0.8 & 0.3 & 0.75 & 0.27 & 0.39 & 0.15 \\
\hline 0.5 & 0.55 & 0.3 & 0.3 & 0.5 & 0.16 & 0.09 & 0.09 \\
\hline 0.25 & 0.55 & 0.3 & 0.35 & 0.25 & 0.05 & 0.03 & 0.03 \\
\hline 0.25 & 0.55 & 0.3 & 0.2 & 0.25 & 0.05 & 0.03 & 0.02 \\
\hline 0.5 & 0.55 & 0.25 & 0.2 & 0.5 & 0.16 & 0.07 & 0.06 \\
\hline 0.75 & 0.55 & 0.25 & 0.2 & 0.75 & 0.27 & 0.12 & 0.10 \\
\hline 1 & 0.55 & 0.25 & 0.7 & 1 & 0.38 & 0.17 & 0.48 \\
\hline 1.25 & 0.55 & 0.35 & 0.7 & 1.25 & 0.49 & 0.31 & 0.62 \\
\hline 1.5 & 0.55 & 0.9 & 0.7 & 1.5 & 0.59 & 0.97 & 0.76 \\
\hline 1.75 & 0.55 & 0.9 & 0.6 & 1.75 & 0.70 & 1.15 & 0.77 \\
\hline 2 & 0.55 & 0.9 & 0.6 & 2 & 0.81 & 1.33 & 0.88 \\
\hline Average & 0.55 & 0.57 & 0.49 & Sum & 6.91 & 8.50 & 7.18 \\
\hline Run Time & 42 & 48 & 42 & Run Time & 42 & 42 & 47 \\
\hline Melt Rate & 0.79 & 0.71 & 0.70 & Melt Rate & 9.9 & 12.1 & 9.2 \\
\hline
\end{tabular}

\section{CONCLUSIONS}

The addition of sugar to MB3 melter feed did not improve melt rate. In addition, glass produced in a sealed crucible has a predicted redox of $>0.33 \mathrm{Fe}^{+2} / \Sigma \mathrm{Fe}$, which is above the DWPF redox limit.

The impact of the addition of sugar to reduce nitrate to nitrogen during the melting process was dramatically different for the MB3 test than the MB2 test. Changes to the feed preparation method may have caused the difference in behavior, but additional tests would be required to verify the cause.

Glass redox is strongly influenced by the addition of sugar. The amount of sugar calculated to reduce the nitrate available in the SRAT product produces glass that exceeds the DWPF upper limit on redox. Small changes in the amount of sugar can significantly shift the glass redox and the relationship between redox and sugar amount is likely non-linear. 
WSRC-TR-2001-00158

Page 7 of 7

\section{REFERENCES}

1. Task Technical and QA Plan for Alternative Process Options to Improve Melt Rate, WSRC-RP-2001-00183, January 31, 2001.

2. Technical Task Request, HLW/DWPF/TTR-00-0044, October 24, 2000.

3. Melt Rate Furnace Laboratory Notebook, WSRC-NB-2000-00106.

4. Melt Rate Furnace Laboratory Notebook, WSRC-NB-2001-00009.

5. M. E. Stone and J. E. Josephs, "Melt Rate Improvement for DWPF MB3: Melt Rate Furnace Testing (U)”, WSRC-TR-2001-00146, Revision 0, March 15, 2001.

6. M. E. Stone and D. P. Lambert, "DWPF Macrobatch 2 Melt Rate Tests", WSRCTR-2000-00395, October 5, 2000.

7. D. K. Peeler and T. H. Lorier, "Melt Rate Improvement for DWPF MB3: Foaming Theory and Mitigation Techniques (U)", WSRC-RP-2001-00351, Revision 0, March 30, 2001.

8. J. E. Josephs, "Run Plan for Frit 200 Macrobatch Three with Sugar in the Melt Rate Furnace (U)", SRT-GPD-2001-0033, March 6, 2001.

9. J. E. Josephs, "Run Plan for Crucible Tests with Macrobatch 3 Baseline Sugar (Sucrose) Reductant (U)", SRT-GPD-2001-001, January 4, 2001.

10. M. E. Stone and D. P. Lambert, "Melt Rate Improvement for DWPF MB3: Feed Preparation (U)”, WSRC-TR-2001-00126, Revision 0, April 1, 2001.

11. K. G. Brown, C. M. Jantzen, and J. B. Pickett, "The Effects of Formate and Nitrate on Reduction/Oxidization (Redox) Process Control for the Defense Waste Processing Facility (DWPF) (U)”, WSRC-RP-97-34, February 5, 1997. 


\author{
Distribution \\ W. D. Kerley, 704-S \\ J. F. Ortaldo, 704-S \\ R. E. Edwards, 704-3N \\ M. R. Norton, 704-27S \\ J. E. Occhipinti, 704-27S \\ J. F. Sproull, 704-30S \\ D. C. Iverson, 704-30S \\ R. J. O'Driscoll, 704-30S \\ L. M. Papouchado, 773-A \\ E. W. Holtzscheiter, 773-A \\ R. H. Spires, 773-A \\ D. A. Crowley, 773-43A \\ S. L. Marra, 704-1T \\ D. F. Bickford, 773-43A \\ C. M. Jantzen, 773-A
}

D. C. Witt, 704-1T

M. E. Stone, 704-1T

D. P. Lambert, 704-1T

M. F. Williams, 704-1T

D. C. Koopman, 704-1T

T. K. Snyder, 773-42A

J. J. Connelly, 773-41A

K. G. Brown, 704-1T

D. R. Best, 773-41A

D.K. Peeler, 773-43A

T.H. Lorier, 773-23A

D. H. Miller, 786-1A

T. B. Edwards, 773-42A

J.C. George, 773-43A

Records (4)

VT QA File 